\title{
Pendidikan Karakter Pada Siswa Melalui Sikap Ilmiah Dengan Menggunakan Model POE2WE
}

\author{
Yusna Megawati Utari ${ }^{1}$, Nana ${ }^{2}$ \\ ${ }^{1}$ Mahasiswa Program Studi Pendidikan Fisika \\ Universitas Siliwangi \\ ${ }^{2}$ Dosen Program Studi Pendidikan Fisika \\ Universitas Siliwangi \\ Tasikmalaya 46115, Jawa Barat, Indonesia \\ Email : yusnamega15@gmail.com
}

\begin{abstract}
Abstrak
Pendidikan Karakter dimaknai sebagai pendidikan nilai, pendidikan budi pekerti, pendidikan moral, dan pendidikan perilaku. Tidak banyak dari siswa yang memiliki karakter tidak sesuai dengan norma-norma yang berlaku. Dengan fisika, siswa dapat mengubah pola pikirnya, salah satunya dengan melalui sikap ilmiah. Maka, penelitian ini bertujuan untuk : (1) memberikan pendidikan karakter pada siswa dengan menggunakan sikap ilmiah sebagai acuan (2) menggunakan model pembelajaran POE2WE untuk memberikan contoh yang baik dalam pendidikan karakter siswa. Sejalan dengan tujuan tersebut, maka penelitian ini menggunakan metode studi pustaka. Pembelajaran dengan model POE2WE merupakan salah satu model pembelajaran yang dapat membantu siswa untuk mendirikan karakter yang baik dan benar dengan cara membangun pengetahuannya sendiri. Dalam pembahasan ini, yaitu dalam pokok pembelajaran sikap ilmiah yang dapat mendidik karakter siswa yang baik dan benar dan menggunakan model POE2WE.
\end{abstract}

Kata kunci : Pendidikan karakter, sikap ilmiah, Model poe2we

\begin{abstract}
Character education is interpreted as value education, character education, moral education, and behavioral education. Not many students have character that is not in accordance with the prevailing norms. With physics, students can change their mindset, one of them is through scientific attitude. Thus, this study aims to: (1) provide character education to students by using scientific attitudes as a reference (2) using the POE2WE learning model to provide a good example in student character education. In line with these objectives, this study uses literature study methods. Learning with the POE2WE model is one of the learning models that can help students to establish good and right character by building their own knowledge. In this discussion, namely in the subject of learning scientific attitudes that can educate good and true student character and use the POE2WE model.
\end{abstract}


Keywords: Character education, scientific attitude, Poe2we models

\section{Pendahuluan}

Karakter adalah salah satu hal yang penting dalam kehidupan berbangsa dan bernegara untuk saat ini. Mengingat kondisi bangsa khususnyaanak bangsa yang masih dalam dunia pendidikan menganggap bahwa karakter itu sudah tidak penting. Maka dari itu, penting untuk kita khususnya sebagai seorang pendidik menrapkan pendidikan karakter dalam diri siswa. (Juliana, Dira. et al., 2017)

Menurut Chusnani, D. (2013) Pendidikan karakter merupakan upayaupaya yang dirancang dan dilaksanakan secara sistematis untuk membantu peserta didik memahami nilai-nilai perilaku manusia yang berhubungan dengan Tuhan Yang Maha Esa, diri sendiri, sesama manusia, lingkungan, dan kebangsaan yang terwujud dalam pikiran, sikap, perasaan, perkataan, dan perbuatan berdasarkan norma-norma agama, hukum, tata krama, budaya, dan adat istiadat. Indikator keberhasilan program pendidikan karakter oleh peserta didik, di antaranya mencakup:

1. Cinta Tuhan dan segenap ciptaanNya (love Allah, trust, reverence, loyalty).

2. Tanggung jawab, Kedisiplinan dan Kemandirian (responsibility, excellence, self reliance, discipline, orderliness)

3. Kejujuran/Amanah dan Arif (trustworthines, honesty, and tactful)

4. Hormat dan Santun (respect, courtesy, obedience)

5. Dermawan, Suka menolong dan Gotongroyong/Kerjasama (love, compass-sion, caring, empathy, generousity, moderation, cooperation)

6. Percaya Diri, Kreatif dan Pekerja keras (confidence, assertiveness, creativity, Resourcefulness, courage, determination, enthusiasm)
7. Kepemimpinan dan Keadilan (justice, fairness, mercy, leadership)

8. Baik dan Rendah Hati (kindness, friendliness, humility, modesty)

9. Toleransi, Kedamaian dan Kesatuan (tolerance, flexibility, peacefulness, unity).

Sikap ilmiah dalam pembelajaran sains sering dikaitkan dengan sikap terhadap sains. Keduanya saling berhubungan dan keduanya mempengaruhi perbuatan. Sikap ilmiah dibedakan dari sekedar sikap terhadap sains, karena sikap terhadap sains hanya terfokus pada apakah siswa suka atau tidak suka terhadap pembelajaran sains. Tentu saja sikap positif terhadap sains akan memberikan kontribusi yang tinggi dalam pembentukan sikap ilmiah siswa tetapi masih ada faktor lain yang memberikan kontribusi (Anwar, Herson. 2009).

Menurut Harlen (1996) (dalam Herson, Anwar. 2009) paling kurang ada empat jenis sikap yang perlu mendapat perhatian dalam pengembangan sikap ilmiah siswa : (1) sikap terhadap pekerjaan disekolah, (2) sikap terhadap diri mereka sendiri sebagai siswa, (3) sikap terhadap ilmu pengetahuan, khususnya sains, dan (4) sikap terhadap objek dan kejadian dilingkungan sekitar. Keempat sikap ini akan membentuk sikap ilmiah yang mempengaruhi keinginan seseorang untuk ikut serta dalam kegiatan tertentu, dan cara seseorang merespon kepada orang lain, obyek, atau peristiwa.

Sikap - sikap ilmiah yang dimaksud adalah sebagai berikut :

- Sikap ingin tahu. Sikap ingin tahu ini terlihat pada kebiasaan bertanya tentang berbagai hal yang berkaitan dengan bidang kajiannya. Mengapa demikian? Bagaimana caranya? Apa saja unsur-unsurnya? Dan seterusnya. 
- Sikap Kritis. Sikap kritis ini terlihat pada kebiasaan mencari informasi sebanyak mungkin berkaitan dengan bidang kajian untuk dibandingbandingkan kelebihan kekurangannya, kecocokan - ketidak cocokannya, kebenaran-dan tidak benarnya, dan sebagainya.

- Sikap terbuka. Sikap terbuka ini terlihat pada kebiasaan mau mendengarkan pendapat, argumentasi, kritik, dan lainnya, walaupun tidak sepaham dengan yang dimaksudkan

- Sikap objektif. Sikap objektif ini terlihat pada kebiasaan menyatakan apa adanya, tanpa diikuti perasaan pribadi

- Sikap rela menghargai karya orang lain. Sikap ini terlihat pada kebiasaan menyebutkan sumber secara jelas sekiranya pernyataan atau pendapat yang disampaikan memang berasal dari pernyataan atau pendapat orang lain.

- Sikap berani mempertahankan kebenaran. Sikap ini menampak pada keterangan membela fakta dan hasil temuan lapangan atau pengembangan walaupun bertentangan atau tidak sesuai dengan teori atau dalil yang ada

- Sikap menjangkau kedepan. Sikap ini dibuktikan dengan selalu ingin membuktikkan hipotesis yang disusunnya demi pengembangan bidang ilmunya. (Anwar, Herson. 2009)

Menurut Nana (2014) Model POE2WE ( Prediction, Observation,
Explanation, Elaboration, Write, and Evaluation) dikembangkan dari model POEW dan model pembelajaran Fisika dengan Pendekatan konstrutivistik. Pengembangan ini dilakukan untuk sebagai penyempurna model kedua sebelumnya. Model $\mathrm{POE}_{2} \mathrm{WE}$ merupakan model pembelajaran yang dikembangkan untuk mengetahui pemahaman peserta didik mengenai suatu konsep dengan pendekatan konstruktivistik.

Maka penelitian ini bertujuan untuk memberikan upaya dalam pendidikan karakter khususnya melalui sikap ilmiah dengan bantuan model pembelajaran POE2WE yang merupakan pendekatan kontruktivisme.

\section{Metode Penelitian}

Penelitian ini menggunakan metode studi pustaka, dengan mengkaji beberapa teori dasar yang relevan dengan topik yang akan dibahas, menggali teori-teori yang relevan dengan pembahasan untuk menemukan konsep-konsep yang sesuai dengan pokok masalah yang dibahas tentang penggunaan model POE2WE. Dan juga untuk menemukan suatu masalah untuk diteliti, dalam arti bukti-bukti atau pernyataan bahwa masalah yang akan diteliti belum terjawab atau belum terpecahkan secara memuaskan atau belum pernah diteliti orang mengenai tujuan, data dan metode, analisa dan hasil dan waktu untuk tempat yang sama. Dalam membahas suatu topik dengan menggunakan studi pustaka beberapa jurnal, buku, ataupun artikel untuk menguji kebenaran topik yang diteliti.

\section{Hasil Penelitian Dan Pembahsan \\ Menurut Nana (2018), Model} POE2WE merupakan model pembelajaran yang dikembangkan untuk mengetahui pemahaman siswa mengenai suatu konsep 
dengan pendekatan konstruktivistik. Model ini membangaun pengetahuan dengan urutan proses terlebih dahulu meramalkan atau memprediksi solusi dari permasalahan, melakukan eksperimen untuk membuktikan prediksi, kemudian menjelaskan hasil eksperimen yang diperoleh secara lisan maupun tertulis, membuat contoh penerapan dalam kehidupan sehari-hari, menuliskan hasil diskusi dan membuat evaluasi tentang pemahaman siswa baik secara lisan maupun tertulis. Penggabungan tahapan-tahapan pembelajaran model POEW dan model pembelajaran Fisika dengan Pendekatan Konstruktivistik maka dapat di susun langkahlangkah pembelajaran model POE2WE secara terinci sebagai berikut:

a) Prediction

Tahap prediction yaitu siswa membuat prediksi atau dugaan awal terhadap suatu permasalahan. Permasalahan yang ditemukan berasala dari pertanyaan dan gambar tentang gerak lurus oleh guru yang ada di LKS/buku siswa sebelum siswa membuat prediksi. Pembuatan prediksi jawaban tahap Prediction pada model POEW identik dengan fase Engagenent pada pendekatan konstruktivistik. Guru mengajukan pertanyaan yang dapat mendorong siswa untuk dapat membuat prediksi atau jawaban sementara dari suatu permasalahan.

b) Observation

Tahap Observation yaitu untuk membuktikan prediksi yang telah di buat oleh siswa. Siswa diajak melakukan eksperimen berkaitan dengan masalah atau persoalan yang di temukan. Selanjutnya siswa mengamati apa yang terjadi, kemudian siswa menguji kebenaran dari dugaan sementara yang telah dibuat. Tahap Observation pada model POEW identik dengan fase Exploration pada pendekatan konstruktivistik.

c) Explanation

Tahap Explanation atau menjelaskan yaitu siswa memberikan penjelasan terhadap hasil eksperimen yang telah dilakukan. Penjelasan dari siswa dilakukan melalui diskusi dengan anggota kelompok kemudian tiap kelompokn mempresentasikan hasil diskusinya di depan kelas. Jika prediksi yang di buat siswa ternyata terjadi di dalam eksperimen, maka guru membimbing siswa merangkum dan memberi penjelasan untuk menguatkan hasil eksperimen yang dilakukan. Namun jika prediksi siswa tidak terjadi dalam eksperimen, maka guru membantu siswa mencari penjelasan mengapa prediksi atau dugaannya tidak benar. Tahap explanation identik dengan fase explanation pada pendekatan konstuktivistik.

d) Elaboration

Tahap elaboration yaitu siswa membuat contoh atau menerapkan konsep dalam kehidupan sehari-hari. Tahap elaboration di ambil dari pendekatan konstruktivistik. Tahap ini guru medorong siswa untuk menerapkan konsep baru dalam situasi baru sehingga siswa lebih memahami konsep yang di ajarkan guru. Tahap ini pengembangan dari pendekatan konstruktivistik.

e) Write

Tahap write atau menulis yaitu melakukan komunikasi secara tertulis,merefleksikan pengetahuan dan gagasan yang dimiliki siswa. Menurut Masingilia dan Wisniowska (1996) dalam 
Ansari (2012) menulis dapat membantu siswa untuk mengekspresikan pengetahuan dan gagasan mereka. Siswa menuliskan hasil diskusi dan menjawab pertanyaan yang ada pada LKS. Selain itu pada tahap write ini, siswa membuat kesimpulan dan laporan dari hasil eksperimen. Tahap ini merupakan pengembangan dari model TTW.

f) Evaluation

Tahap Evaluationyaitu evaluasi terhadap pengetahuan, keterampilan dan perubahan proses berfikir siswa. Pada tahap ini siswa di evaluasi tentang materi gerak lurus berupa lisan maupun tulisan.Tahap ini merupakan pengembangan dari pendekatan konstruktivistik.

Penerapan dalam mengupayakan adanya karakter yang baik dan benar khususnya mencakup sikap ilmiah dapat dilakukan dengan model POE2WE yaitu Prediction, Observation, Eksplanation, Elaboration, Write, dan Evaluation. Dari keenam unsur dari model POE2WE tersebut semuanya memiliki ikatan untuk mendidik karakter siswa sebagaimana halnya seperti sikap seorang ilmuan, yaitu sikap ilmiah. Tetapi dari keenam unsur pasti memiliki perbedaan kegiatan pendidik karakternya masing-masing.

Berikut ini adalah penerapan sikap ilmiah guna mendidik karakter yang baik dan sesuai dengan menggunakan Model POE2WE :

\section{a. Prediction}

Dalam prediction atau prediksi, siswa dapat berfikir secara kritis, logis.

Dengan berfikir kritis siswa mudah memahami sudut pandang orang lain, memiliki banyak alternatif jawaban dan ide yang kreatif, dapat menjadi teman kelompok yang baik dan dapat diandalkan, lebih mandiri menghadapi masalah, dapat menemuka banyak peluang baru, dll. Sedangkan dengan berfikir logis siswa akan memikirkan terlebih dahulu sebelum melakukan segala sesuatu, baik itu sesuatu yang baik ataupun yang buruk. Selalin itu, dengan berfikir logis siswa akan meningkatkan rasa cinta dan dan kebenaran, lalu menghindarkan diri dari kekeliruan karena informasi yang tidak benar.

\section{b. Observation}

Dengan berobservasi, siswa bisa berkomunikasi dengan baik bersama guru atau teman sebaya-nya, dan siswa juga bisa bekerja sama dengan temannya, dan selalu jujur dalam berbuat dan berbicara, karena jujur adalah salah satu sikap ilmuwan yang harus diterapkan pada siswa.

\section{c. Explanation}

Berbeda dengan prediction dan observation, dalam explanation siswa akan menjelaskan apa yang ia tahu kepada teman yang tidak tahu, tidak hanya itu ia juga akan dengan sangat menghargai guru yang menjelaskan, karena ia pun merasakan bahwasanya menjelaskan atau memberi penjelasan bukanlah hal yang mudah. Selain itu, dengan explanation siswa akan menghormati orang yang lebih tua darinya.

\section{d. Elaboration}

Dengan elaboration, siswa akan menjadi contoh yang baik untuk orang sekitarnya dan menjadi panutan, baik itu untuk orang lain ataupun teman sendiri.

\section{e. Write}

Dalam write ini, siswa bisa menyadari bahkan memperbaiki kesalahannya sendiri, dan ia akan mencatat 
atau mengingat untuk tidak melakukan hal buruk yang sama untuk kedua kalinya.

f. Evaluation

Dengan berevaluasi, siswa bisa disiplin dalam mengerjakan tugas dan pengumpulan tugas, juga didalam evaluasi ini siswa akan memiliki integritas yang tinggi dalam pembelajaran.

Dari data diatas dapat kita lihat bahwasanya model POE2WE ini dapat mendidik karakter siswa sesuai dengan sikap seorang ilmuwan. Mengapa demikian, karena pada model POE2WE ini unsur-unsur didalamnya (yakni : Prediction, Observation, Eksplanation, Elaboration, Write, dan Evaluation) mampu memberikan kesan positif yang dapat mendidik dan membangun sikap ilmuwan pada siswa.

\section{Kesimpulan}

Berdasarkan hasil pembahasan diatas, dapat disimpulkan bahwa model POE2WE dapat memberi pendidikan karakter yang baik yang sesuai dengan karakter atau sikap seorang ilmuwan, yaitu sikap ilmiah.

\section{Referensi}

Anwar, Herson. 2009. Penilaian Sikap Ilmiah Dalam Pembelajaran Sains. Jurnal Pelangi Ilmu. 2(5): 106-112.

Chusnani, Diana. 2013. Pendidikan Karakter Melalui Sains. Jurnal Kebijakan dan Pengembangan Pendidikan. 1(1); 10-11.

Juliana, Diara., Rosma Elly., Nurmasyitah. 2017. Penanaman Karakter Melalui Metode Pembiasaan Pada SD Negeri 27 Aceh. Jurnal Ilmiah Pendidikan Guru Sekolah Dasar. 2(4). 9.
Nana, (2018). Penggunaan Pendekatan Konflik Kognitif untuk Remediasi Miskonsepsi Pembelajaran Suhu Dan Kalor. [online].Tersedia:https://www.jurna 1.fkip.uns.ac.id/index.php/snps/artic le/view/12476. [19 Februari].

Nana. 2018. Implementasi Model POE2WE Dengan Pendekatan Saintifik Dalam Pembelajaran Gerak Lurus Di SMA. Seminar Nasional Pendidikan Sains.[online]. Tersedia:https://www.jurnal.fkip.un s.ac.id/index.php/snps/article/view/ 12477. [19 Februari]. 